\title{
Effects of physical activity on food intake
}

Citation for published version (APA):

Melzer, K., Kayser, B., Saris, W. H., \& Pichard, C. (2005). Effects of physical activity on food intake. Clinical Nutrition, 24(6), 885-895. https://doi.org/10.1016/j.clnu.2005.06.003

Document status and date:

Published: 01/01/2005

DOI:

10.1016/j.clnu.2005.06.003

Document Version:

Publisher's PDF, also known as Version of record

\section{Please check the document version of this publication:}

- A submitted manuscript is the version of the article upon submission and before peer-review. There can be important differences between the submitted version and the official published version of record.

People interested in the research are advised to contact the author for the final version of the publication, or visit the DOI to the publisher's website.

- The final author version and the galley proof are versions of the publication after peer review.

- The final published version features the final layout of the paper including the volume, issue and page numbers.

Link to publication

\footnotetext{
General rights rights.

- You may freely distribute the URL identifying the publication in the public portal. please follow below link for the End User Agreement:

www.umlib.nl/taverne-license

Take down policy

If you believe that this document breaches copyright please contact us at:

repository@maastrichtuniversity.nl

providing details and we will investigate your claim.
}

Copyright and moral rights for the publications made accessible in the public portal are retained by the authors and/or other copyright owners and it is a condition of accessing publications that users recognise and abide by the legal requirements associated with these

- Users may download and print one copy of any publication from the public portal for the purpose of private study or research.

- You may not further distribute the material or use it for any profit-making activity or commercial gain

If the publication is distributed under the terms of Article $25 \mathrm{fa}$ of the Dutch Copyright Act, indicated by the "Taverne" license above, 


\title{
Clinical \\ Nutrition
}

ELSEVIER

\section{REVIEW}

\section{Effects of physical activity on food intake}

\author{
Katarina Melzer ${ }^{a}$, Bengt Kayser ${ }^{b}$, Wim H.M. Saris ${ }^{c}$, Claude Pichard ${ }^{a, *}$
}

\author{
${ }^{a} G e n e v a$ University Hospital, 24 Micheli-du-Crest, 1211 Geneva 14, Switzerland \\ $\mathrm{b}$ Institute of Movement Sciences and Sports Medicine, University of Geneva, Switzerland \\ 'Department of Human Biology, Nutrition and Toxicology Research Institute NUTRIM, \\ University of Maastricht, The Netherlands
}

Received 13 April 2005; accepted 8 June 2005

KEYWORDS
Exercise;
Dietary intake;
Body weight;
Energy expenditure;
Energy homeostasis;
Appetite

KEYWORDS

Exercise;

Dietary intake;

Energy expenditure;

Appetite

\begin{abstract}
Summary The understanding of the effect of physical activity (PA) on food intake is imperative for considering PA as an additional tool for prevention and treatment of many diseases. Prolonged strenuous PA performed on a regular basis causes an increase in overall energy turnover, and leads either to loss of body weight, or to an increased food intake. When leading to loss of body weight, PA may be used as a therapeutic adjunct in the treatment of obesity. When increasing food intake to compensate for increased energy expenditure and maintaining body weight, PA, by increasing intake of other constituents of food like minerals and vitamins, may contribute to micronutrient deficiency coverage. However, the type of activity, as well as body composition of the individuals engaging in sport, play an important role in food intake regulation and its changes with time. Some studies indicate that shortterm exercise does not have the same effect on food intake as long-term exercise and that eventual increase in food intake due to increased PA does not follow the same pattern in obese as in lean individuals. To better understand the relationship between PA on food intake, current findings on this topic will be summarized in this paper. (c) 2005 Elsevier Ltd and European Society for Clinical Nutrition and Metabolism. All rights reserved.
\end{abstract}

\section{Contents}

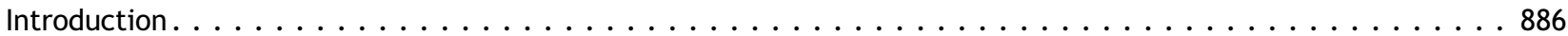

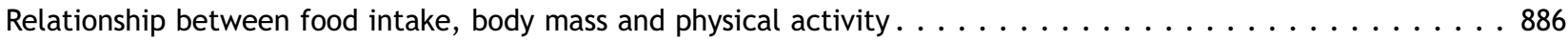

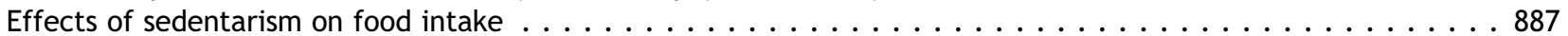

Energy intake in response to high-energy requirements $\ldots \ldots \ldots \ldots \ldots \ldots \ldots \ldots \ldots \ldots \ldots$

Effect of short-term exercise on food intake $\ldots \ldots \ldots \ldots \ldots \ldots \ldots \ldots \ldots \ldots \ldots \ldots$

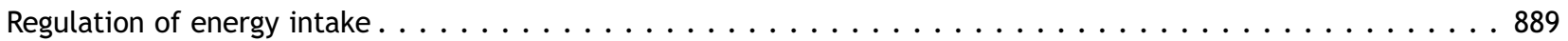

*Corresponding author. Tel.: +4122372 93 49; fax: +41223729363.

E-mail address: Claude.Pichard@medecine.unige.ch (C. Pichard). 


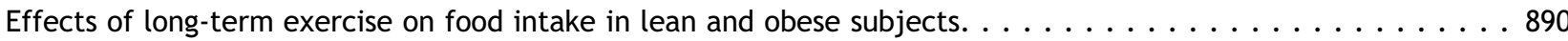

Conclusion . . . . . . . . . . . . . . . . . . . . . . . . . . . . . . . . . . . . 894

Acknowledgement . . . . . . . . . . . . . . . . . . . . . . . . . . . . . . . . . 894

References. . . . . . . . . . . . . . . . . . . . . . . . . . . . . . . . . . . . . 894

\section{Introduction}

Physical activity (PA) is closely interrelated with energy intake. The working body requires energy and nutrients in order to fuel activity and function. $\mathrm{PA}$, on the other hand, manipulates energy expenditure and regulates the use of fuels. When prolonged strenuous PA is performed on a regular basis, it causes an increase in overall energy turnover ${ }^{1}$ and leads either to loss of body weight, or to a need for an increase in food intake. ${ }^{2}$ Nevertheless, many questions remain open in that regard. For example: is increased energy expenditure due to short-term PA automatically compensated for by changes in energy intake? Does shortterm exercise have the same effect on energy intake as long-term exercise? Does the eventual increase in food intake due to increased PA follow the same pattern in obese as in lean individuals?

Thus, to which extent the energy intake is regulated through PA still remains unclear and further research is required that may provide useful information for public health guidelines. For example, vigorous PA on a daily basis not only increases the overall intake of energy, ${ }^{3}$ but also of other constituents of food, such as micronutrients. Therefore, in conjunction with low-energy food abundant in minerals and vitamins, PA may not only enhance human health in general, ${ }^{4}$ but also prevent micronutrient deficiencies. ${ }^{5}$

Therefore, reaching a clear understanding of the relationship between PA and food intake may prove valuable in choosing the most beneficial approach for individual and societal health management. The aim of this paper is thus to summarize the state-ofart in our understanding of the effects of PA on energy and nutrient intake.

\section{Relationship between food intake, body mass and physical activity}

Mayer et al. ${ }^{6,7}$ performed several of the earlier studies, on both animals and humans, examining the effect of exercise on body mass and food intake. To the extent that it is legitimate to draw an equivalence between purely experimental results and the results of population studies, a remarkable parallelism was found between the two. ${ }^{7}$ In order to provide an accessible overview of these and other findings on the same topic, the relationship between food intake, exercise and body mass is conceptualized in Fig. 1 .

The first study was performed in rats exercising on a treadmill. ${ }^{6}$ It was observed that an introduction of short periods of exercise ( $1 \mathrm{~h}$ or less/day) in the life of normal rats were not followed by an increase in food intake over the amount corresponding to absolute inactivity. In fact, a significant decrease in food intake occurred indicating a probable greater availability of endogenous fuel mobilization due to enhanced vascularization of body tissues. ${ }^{6}$ As a result, the mass of the animals

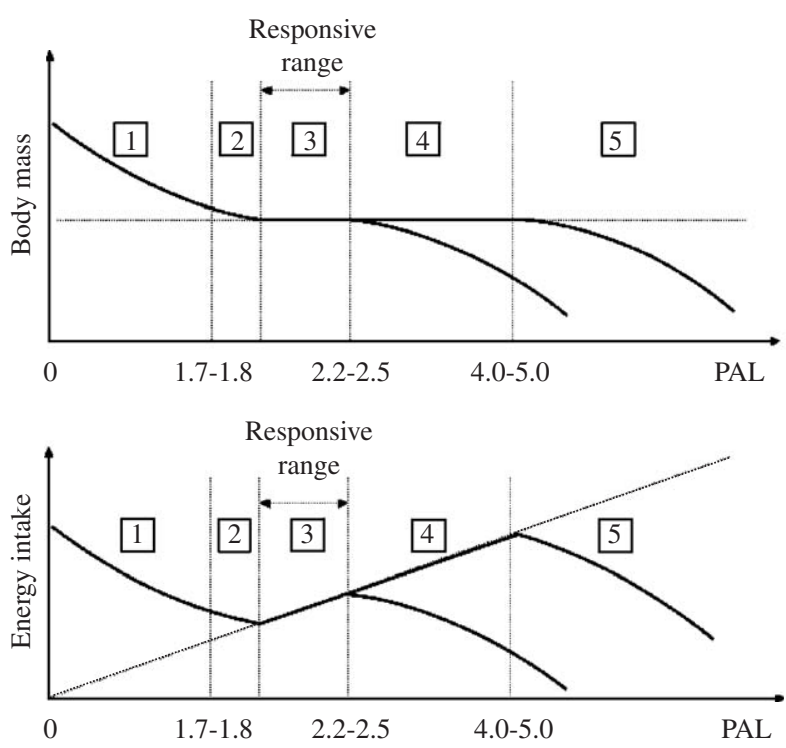

Figure $1 \mathrm{~A}$ model showing the relationship between Physical Activity Level (PAL), body mass and food intake; zone 1: decrease in PAL and increase in sedentariness does not induce compensatory reduction in food intake and leads to increase in body mass; zone 2: introduction of acute physical activity on a short-term basis suppresses food intake, due to mobilization of stored fuels, and leads to decrease in body mass; zone 3 (responsive range): moderate to intense physical activity performed regularly and on a long-term basis by lean individuals increases food intake accordingly and maintains body mass; obese individuals, due to their excess energy storage, do not show significant changes in food intake; the PAL level in the general population has an upper limit around 2.2-2.5 (zone 4), and in highly trained subjects around 4.0-5.0 (zone 5). Above these values, the human body is not capable to cover the high-energy expenditure, and loss of body mass occurs as a consequence. 
decreased. This range of activity was called "nonresponsive" with respect to food consumption. When the duration of exercise increased more than $1 \mathrm{~h} /$ day, food intake increased linearly and the body mass was maintained. This range of activity was termed "normal" because of the proportional response of exercise on food intake. Once the exercise was prolonged to more that $6 \mathrm{~h} /$ day, the animals became exhausted, lost body mass, food intake decreased and appearance deteriorated. As the increase in the activity was not accompanied by a corresponding increase in food intake, this range of PA was also considered as "non-responsive".

The second study of Mayer et al. ${ }^{7}$ used an indirect method of assessing PA based on job classification along with dietary intake records in Indian men. Although the study was not well controlled it was concluded that men employed in jobs requiring physical labour increased energy intakes with increased demands for PA while maintaining their lean body mass constant. On the other hand employees with a sedentary job had a disproportional larger energy intake compared to the PA levels. Thus, energy intake balanced with activity level only within a certain zone. By analogy with previously used terminology ${ }^{6}$ this zone was called "normal activity range".

\section{Effects of sedentarism on food intake}

In mice, under laboratory conditions, the decrease in energy expenditure due to reduced activity is not accompanied by a corresponding decrease in energy intake. ${ }^{8}$ Thus, physical inertia in mice is considered to play an essential role in the development of obesity.

The influence of inactivity on energy balance was investigated in humans by Murgatroyd et al. ${ }^{9}$ Twoday measurements of energy expenditure in the respiration chamber, and ad libitum food intake were measured in eight normal-weight male subjects. The limited PA did not induce a decrease in food intake, and thus resulted in a positive energy balance. When total energy expenditure data was compiled from 22 studies that used the doubly labelled water method, ${ }^{10}$ a considerable variation in body fatness was present among sedentary individuals, again suggesting that a low rate of non-basal energy expenditure is a predisposing factor for obesity.

More recent studies with humans also examined the occurrence of positive energy balance as a result of decreased PA. Stubbs et al. ${ }^{11}$ attempted to assess the effect of an imposed sedentary routine on energy intake and nutrient balance in six lean men (Fig. 1, zone 1). Each subject was studied during a sedentary $(1.4 \times$ resting metabolic rate $(\mathrm{RMR}))$ and an active $(1.8 \times \mathrm{RMR})$ regime, in protocols that involved 7 days of continuous monitoring in the respiration chamber. It was concluded that reducing the level of PA from 1.8 to $1.4 \times \mathrm{RMR}$ did not induce a compensatory reduction of energy intake and led to a significant positive energy balance, most of which was stored as fat.

A review of cross-sectional data from double labelled water studies in adults ${ }^{12}$ supports the latter. The resulting estimate of the threshold of PA associated with weight control is around $1.8 \times$ RMR. Physically active men $(>1.75 \times$ RMR $)$ had lower body mass index than did those with lower energy expenditures. Previously obese women whose activity was above $1.75 \times$ RMR were generally able to maintain their reduced weight, whereas half of the less active women gained weight. Saris et al. ${ }^{13}$ concluded that, although definitive data are lacking, a physical activity level (PAL) of 1.7-1.8 is required to prevent transition to overweight or obesity.

\section{Energy intake in response to high-energy requirements}

Animals and humans who engage regularly in moderate to intense PA are capable of maintaining their lean body mass. ${ }^{6,7}$ An important aspect of the maintenance of energy balance during high-intensity endurance exercise is an adjustment of food intake to high-energy requirements. An example of daily energy intake in endurance, strength, and team sport athletes are presented in Table $1 .{ }^{14}$ The nutritional information about habitual food intake was obtained from a 4 or 7-day food diary on athletes, who trained at least $1-2 \mathrm{~h} /$ day and competed mostly on an international level.

Food intake and energy expenditure was studied in four cyclists during the 22-day race of the Tour de France. ${ }^{15}$ The purpose of the study was to verify whether the energy intakes of the cyclists were in agreement with the energy expenditure on a race that could be considered as one of the most strenuous endurance activities that exist $(4000 \mathrm{~km}$ long, including 30 mountain passages (up to $2700 \mathrm{~m}$ altitude)). ${ }^{16}$ Based on the double-labelled water technique, the cyclists reached an average daily metabolic rate of 4.3-5.3 times basal metabolic rate. The decrease in their body mass and body composition was not considered significant, and all 
Table 1 Daily energy intake in endurance, strength, and team sport athletes.

\begin{tabular}{|c|c|c|c|c|c|}
\hline \multirow[t]{2}{*}{ Type of sport } & \multirow[t]{2}{*}{ Sex } & \multirow[t]{2}{*}{$n$} & \multirow{2}{*}{$\begin{array}{l}\text { Age in years } \\
\text { Mean } \pm S D\end{array}$} & \multicolumn{2}{|c|}{ Energy intake $\left(\mathrm{kJ} / \mathrm{kg}^{-1}\right)$} \\
\hline & & & & Mean & Range \\
\hline \multicolumn{6}{|l|}{ Endurance } \\
\hline Cycling (Tour de France ${ }^{\dagger}$ ) & $M$ & 5 & $26 \pm 3$ & 347 & $286-388$ \\
\hline Cycling (Tour de l'Avenir) & M & 4 & $24 \pm 2$ & 316 & $247-378$ \\
\hline Triathlon $^{\dagger}$ & $M$ & 33 & $26 \pm 3$ & 272 & $246-295$ \\
\hline Cycling, amateur & $M$ & 14 & $20 \pm 1$ & 253 & $207-314$ \\
\hline Marathon skating ${ }^{\dagger}$ & $M$ & 5 & $33 \pm 5$ & 222 & $175-294$ \\
\hline Swimming ${ }^{\dagger}$ & $M$ & 20 & $18 \pm 3$ & 221 & $119-300$ \\
\hline Rowing $^{\dagger}$ & $M$ & 18 & $22 \pm 2$ & 189 & $167-225$ \\
\hline Running $^{\dagger}$ & $M$ & 56 & $30 \pm 5$ & 193 & $127-311$ \\
\hline Rowing & $\mathrm{F}$ & 8 & $23 \pm 2$ & 186 & $140-200$ \\
\hline Cycling, amateur ${ }^{\dagger}$ & $\mathrm{F}$ & 21 & $23 \pm 4$ & 164 & $115-215$ \\
\hline Running ${ }^{\dagger}$ & $\mathrm{F}$ & 18 & $31 \pm 5$ & 168 & $123-218$ \\
\hline Sub-top swimming & $\mathrm{F}$ & 50 & $12 \pm 2$ & 200 & $92-338$ \\
\hline \multicolumn{6}{|l|}{ Strength } \\
\hline Body building ${ }^{\dagger}$ & $M$ & 8 & $30 \pm 7$ & 157 & $106-183$ \\
\hline $\mathrm{Judo}^{\dagger}$ & $M$ & 4 & $23 \pm 1$ & 157 & $76-210$ \\
\hline Weight lifting & $M$ & 7 & $27 \pm 4$ & 167 & 99-203 \\
\hline $\mathrm{Judo}^{\dagger}$ & $M$ & 28 & $18 \pm 1$ & 177 & $60-325$ \\
\hline Top gymnastics & $\mathrm{F}$ & 11 & $15 \pm 1$ & 158 & $91-216$ \\
\hline Sub-top gymnastics & $\mathrm{F}$ & 41 & $13 \pm 1$ & 206 & $113-334$ \\
\hline Body buildingc ${ }^{\dagger}$ & $\mathrm{F}$ & 4 & $25 \pm 5$ & 110 & $91-133$ \\
\hline \multicolumn{6}{|l|}{ Team sport } \\
\hline Water polo ${ }^{\dagger}$ & $M$ & 30 & $24 \pm 3$ & 194 & $92-299$ \\
\hline Soccer $^{\dagger}$ & $M$ & 20 & $20 \pm 3$ & 192 & $118-287$ \\
\hline Hockey ${ }^{\dagger}$ & $M$ & 8 & $27 \pm 2$ & 181 & $167-217$ \\
\hline Volleyball & $\mathrm{F}$ & 9 & $23 \pm 3$ & 140 & $101-229$ \\
\hline Hockey $^{\dagger}$ & $\mathrm{F}$ & 9 & $24 \pm 4$ & 145 & 91-199 \\
\hline Handball & $\mathrm{F}$ & 8 & $22 \pm 2$ & 142 & $78-271$ \\
\hline Total & 419 & & & & \\
\hline
\end{tabular}

*Adapted from: van Erp-Baart AM, et al., 1989. Nationwide survey on nutritional habits in elite athletes. Part I. Energy, carbohydrate, protein, and fat intake. Int J Sports Med, 10(Suppl. 1): S3-S10.

$\dagger$ Including World, European, and Olympic medal winners.

four subjects remained in energy balance (Fig. 1, zone 3).

Nevertheless, there is a limit to the performance of an organism set by energy intake and energy expenditure. The PA level in the general population was shown to have an upper limit of approximately 2.2-2.5 (Fig. 1, zone 4). ${ }^{17}$ The upper limit of sustainable metabolic rate is approximately twice as high in endurance athletes (Fig. 1, zone 5), as a result of long-term exercise training, increased fatfree mass and consumption of carbohydrate-rich food during exercise. ${ }^{16,17}$ Above these values, a human body is not capable to cover the high-energy expenditure with energy intake, and loss of body mass occurs as a consequence, which together with symptoms like fatigue, mood changes and sleep problems constitutes the overtraining syndrome. ${ }^{18}$
When regular PA is introduced in the otherwise sedentary population, one would thus expect that the increased energy expenditure accomplished through exercise would rapidly lead to increased dietary intake. However, as shown by the studies cited below, this reasoning is too simplistic. The type of activity, as well as body composition of the individuals engaging in sport, play an important role in food intake regulation and its changes with time.

\section{Effect of short-term exercise on food intake}

In highly physically trained persons, the enormous daily energy expenditure due to vigorous exercise is 
thus generally matched by a high-energy intake (Fig. 1, zone 3). ${ }^{15}$ By contrast, under more normal conditions, increased energy expenditure due to short-term PA is not automatically compensated for by changes in energy intake in both, lean and obese individuals (Fig. 1, zone 2). ${ }^{19}$

King et al. ${ }^{20}$ examined the effect of different types of short-term exercise on energy intake. Twenty-three healthy lean male subjects (21-27 years, mean $B M I=24.2 \mathrm{~kg} / \mathrm{m}^{2}$ ) were randomly assigned to a control, low-intensity exercise treatment (cycling at $30 \% \mathrm{VO}_{2}$ max for $\sim 60 \mathrm{~min}$ ) and high-intensity exercise treatment (cycling on $70 \%$ $\mathrm{VO}_{2}$ max for $\sim 30 \mathrm{~min}$ ) in the first study, and to a control, short (mean time $=26 \mathrm{~min}$ ) and high duration (mean time $=52 \mathrm{~min}$ ) exercise treatment of high intensity in the second study. For energy cost calculation, expired air was collected periodically during each of the exercise sessions using a modified Douglas bag system. Energy and macronutrient intakes were measured by recorded intakes for the next 2 days. It was concluded that short-term low-intensity exercise did not induce a suppression of hunger, and that hunger ratings at no time significantly deviated from the hunger in the session that included a rest period. Only highintensity exercise induced a suppression of hunger. Long duration, high-intensity exercise had a stronger effect on energy intake than short duration exercise period. It was concluded that high-dose exercise suppresses appetite and induces an exercise-induced anorexia.

In another study, King et al. $^{21}$ examined the effect of high doses of exercise (exercise-induced energy expenditure of $\sim 1200 \mathrm{kcal}$ ) on energy intake within $48 \mathrm{~h}$. Douglas bags were used to collect the expired air during the exercise in order to calculate the total energy cost. Energy intake was monitored using self-recorded food diaries. The study results suggested that a high dose of exercise occurring on a single day failed to have any effect on energy intake within the same day or on the day immediately after the exercise, compared with days of no exercise. The results demonstrated that a substantial but acute increase in energy expenditure due to intense exercise does not automatically increase hunger or energy intake within $48 \mathrm{~h}$.

The effect on energy intake of two levels (30 vs. $90 \mathrm{~W}$ ) of programmed exercise on a cycle ergometer for $40 \mathrm{~min} / \mathrm{d}$ during a 3-day period were compared in nine obese and non-obese women. ${ }^{22}$ It was found that intake of liquid meals $(1.04 \mathrm{kcal} / \mathrm{g}) 15 \mathrm{~min}$ after the exercise was significantly lower after the strenuous than after the moderate exercise in the non-obese women, but was not different after the two conditions in the obese women.
To study the effect of acute exercise on caloric intake in normal-weight young people, food intake was monitored in 10 men and 10 women during a period of 5 consecutive days. ${ }^{23}$ All exercise was done on a treadmill and oxygen consumption was measured during the exercise period for energy cost evaluation. Throughout the protocol, subjects obtained all their food from a specially equipped metabolic kitchen in a research setting. All items not eaten were returned to the metabolic kitchen for weighing. Men responded to 5-day acute exercise with increased caloric intake $(208 \pm$ $64 \mathrm{kcal} / \mathrm{d}$ ), which was insufficient to compensate for the caloric cost of exercise $(596 \mathrm{kcal} / \mathrm{d}$ above RMR). Women did not change their caloric intake despite expending $382 \mathrm{kcal} / \mathrm{d}$ during exercise. Consequently, both normal-weight men and women were found to be in negative caloric balance during the exercise period.

These studies, as well as many others, ${ }^{24-26}$ reported a negative energy balance after a shortterm increase of energy expenditure. The findings support the first results presented by Mayer et al. ${ }^{6}$ on suppressed dietary intake with introduction of acute PA (Fig. 1, zone 2). At that time, Mayer speculated that a reduction in food intake occurred because of the greater availability of body reserves due to changes of circulatory conditions. More recent studies performed on rats confirmed that blood glucose and free fatty acids levels, as well as plasma lactate levels are all increased during and after short-term exercise. ${ }^{27}$ Thus, the mobilization of stored fuels into the blood may indeed play an important role in the inhibition of food intake. It was also found that exercise is accompanied by an increase in the release of glucagon, which in combination with other satiety factors such as cholecystokinin, cytokines and serotonin suppresses food intake. King et al. ${ }^{28}$ reviewed studies reporting the effects of exercise on appetite control in humans and concluded that an elevation of body temperature, increased levels of lactic acid and an increase of tumor necrosing factor are all possible mechanisms that induce the suppression of hunger.

\section{Regulation of energy intake}

The absence of a compensatory effect in response to an exercise-induced energy deficit would not be expected to continue indefinitely; otherwise a considerable loss of body mass would occur. At some stage, a regulatory mechanism must trigger an increase in energy intake in order to match 
energy expenditure. This mechanism reflects an active regulatory process within a human body, termed energy homeostasis. ${ }^{29}$ Its variation is associated with changes in body weight and more specifically, with variations in protein and fat reserves. ${ }^{30}$ Since fat reserves represent the most unstable depot of the body, ${ }^{30}$ the main role of energy homeostasis is to promote stability in a body fuel stored as adipose tissue. ${ }^{31}$

The ingestion of food and expenditure of energy are regulated by a large number of mechanisms within the central nervous and hormonal system. Different signals reflecting the metabolic state arise from different peripheral tissues, including white adipose tissue, gastrointestinal tract, thyroid, adrenals, muscle, and reproductive organs. ${ }^{32}$ The signals with an anabolic effect stimulate food intake and promote weight gain (e.g. neuropeptide $\mathrm{Y}$, ghrelin); those with a catabolic effect decrease food intake and promote depletion of body fat (e.g. insulin, leptin, corticotropin-releasing hormone, propiomelanocortin). ${ }^{33}$ Weight loss induced by, for example, prolonged exercise lowers insulin and leptin levels, which in turn activate anabolic and inhibits catabolic effectors, thereby promoting the recovery of lost weight. ${ }^{34}$

Although previous evidence suggests that there is a weak coupling between energy intake and energy expenditure in the short term (1-3 days), Edholm et al. ${ }^{35}$ confirmed that over longer periods of time, 7 days and more, the correlation between energy intake and expenditure improves. They studied this regulation between energy intake and output in military cadets with a relative high level of daily exercise. However, in well-trained athletes this mechanism must be very well regulated in order to avoid negative energy balance and thus fuel shortage to perform physically. It is suggested in some of the studies that intake follows expenditure with a 2-day interval, although this lag has not been confirmed by others. Saris ${ }^{36}$ studied this phenomenon in professional cyclists during the Tour de France where expenditure levels are extremely high but also vary variably over the days ranging from 4302 to $7648 \mathrm{kcal} /$ day. The correlation coefficient was calculated between the individual moving averages for energy expenditure and energy intake over $2-5$ days in four athletes. The data clearly showed that the correlation coefficients did not improve further taken a period of 3 days into account. (Range 0.80-0.95).

The observed 3-day period is interesting and indicates that the 2-day period suggested by Edholm $^{37}$ seems to represent a physiological phenomenon under the conditions of hard physical work. Many of the compensating mechanisms previously suggested like body temperature, ${ }^{27,38,39}$ blood lipids, ${ }^{40,41}$ glucose or insulin concentrations, ${ }^{40,42}$ might well come into play on a shortterm basis. Long-term regulatory mechanisms like adipose tissue-related factors such as leptin ${ }^{43,44}$ are also known now. But for periods around 3-7 days no good physiological mechanisms are yet available.

\section{Effects of long-term exercise on food intake in lean and obese subjects}

It is clear that, as energy output is increased through exercise, in order to maintain body mass, an individual must increase energy intake to match expenditure. The lean marathon-runner eats much more calories than his sedentary counterpart. ${ }^{45}$ Many reports in the literature confirm the existence of this balancing act over the long term. Even though the present obesity epidemic needs more insight into the effects of increasing energy expenditure in obese and lean individuals, several studies suggest that the increase of PA is less accurately matched by a corresponding increase of energy intake in obese than in lean individuals (Table 2).

Leon et al. ${ }^{46}$ studied six sedentary obese men aged 16-31 years who completed 16 weeks of $90 \mathrm{~min}$ vigorous walking, 5 days/week, on a treadmill at up to $5.2 \mathrm{~km} / \mathrm{h}$ on a $10 \%$ grade, expending about $1100 \mathrm{kcal}$ per session. Physical work capacity was assessed by means of the modified Balke multistage treadmill exercise test protocol. There was no attempt to influence their dietary habits during this period of time, and eating patterns were monitored by 3-day dietary records before exercise and at $4,8,12$, and 16 weeks of training. Monitored food intake initially increased and then progressively decreased below pretraining level. As a result the obese men lost an average $5.7 \mathrm{~kg}$ of body mass, representing the sum of $5.9 \mathrm{~kg}$ lost as fat and $0.2 \mathrm{~kg}$ gained as lean tissue.

The effect of exercise on spontaneous energy intake in obesity was studied by Woo et al. ${ }^{47}$ as well. In their study, six obese women were hospitalized as a part of a metabolic experiment. They underwent three 19-day treatments-one sedentary (no exercise), the second with treadmill exercise increasing daily expenditure to $110 \%$ (mild) of sedentary expenditure, and the third with the treadmill exercise increasing daily energy expenditure to $125 \%$ (moderate) of sedentary expenditure. Energy expenditure was monitored with daily activity diaries and indirect calorimetry 
determinations of all the activities recorded, while voluntary intake was covertly examined by weighing all the items before and after serving. Although the expenditure increased significantly from 2221 to $2419 \mathrm{kcal} / \mathrm{day}$ during mild treatment and to $2714 \mathrm{kcal} /$ day during moderate treatment, the results suggested that mean daily energy intake was not different between the three treatments. It was concluded that moderate realistic levels of PA, which required $39 \mathrm{~min} /$ day of brisk walking at mild and $96 \mathrm{~min} /$ day at moderate levels, was not compensated by increased energy intake in these obese women, at least not within the time frame of the study.

In order to study if this effect would be sustained over a longer time period, a second group of three obese female volunteers was maintained for all three 19 -day periods at $125 \%$ of their sedentary expenditures. ${ }^{48}$ Mean daily intake of $1903 \mathrm{kcal} /$ day and expenditure of $2882 \mathrm{kcal} /$ day did not change during these 57 days, resulting in lipolysis and consistent body mass loss of $0.12 \mathrm{~kg} / \mathrm{day}$. The study showed that an increase in expenditure during a prolonged period of time did not induce any changes in energy intake. This suggests that in a state of a positive energy/fat reserve there is a possible uncoupling of the intake of energy from the expenditure of energy such as in these obese women, at least in the settings and durations of the studies cited.

A much longer exercise program, lasting 8 months, was performed by 120 sedentary, overweight or obese men and women $(B M I=25-35)$ aged 40-65 years. ${ }^{49}$ The subjects were randomly assigned to 1 of 3 exercise training groups: high amounts/vigorous intensity $(32 \mathrm{~km} /$ week of jogging at $\left.\mathrm{VO}_{2} \quad \max =65-80 \%\right)$, low amount/vigorous intensity $\left(19.2 \mathrm{~km} /\right.$ week of jogging at $\mathrm{VO}_{2} \max =$ 65-80\%) and low amount/moderate intensity $\left(19.2 \mathrm{~km} /\right.$ week of walking at $\left.\mathrm{VO}_{2} \max =40-55 \%\right)$. The subjects were consuming ad libitum food intake. Even so, the high-amount/vigorous-intensity group lost $2.9 \pm 2.8 \mathrm{~kg}$ body mass and $4.8 \pm 3.0 \mathrm{~kg}$ fat mass; the low-amount/moderateintensity group lost $0.9 \pm 1.8 \mathrm{~kg}$ body mass and $2.0 \pm 2.6 \mathrm{~kg}$ fat mass; and the low-amount/vigorous intensity group lost $0.6 \pm 2.0 \mathrm{~kg}$ body mass and $2.5 \pm 3.4 \mathrm{~kg}$ fat mass. The controls gained $+1.0 \pm$ $2.1 \mathrm{~kg}$ and $+0.4 \pm 3.0 \mathrm{~kg}$ body mass and fat mass, respectively. There were no significant changes in energy intake for any group. These findings again suggest an uncoupling of energy intake from expenditure in subjects with an excess of body energy reserves.

In order to clarify the effect of exercise-related factors on the energy intake of normal-weight individuals, non-obese women were studied using the same protocol ${ }^{47}$ as previously in comparable environments. ${ }^{3}$ Thus, five non-obese women underwent three 19-day treatment periods in which PA was modified. Total daily expenditure was increased to $114 \pm 4 \%$ through mild exercise and to $129 \pm 3 \%$ through moderate exercise. Intake was estimated by weighing the platters before and after serving and expenditure was monitored with daily activity diaries and indirect calorimetry determinations of the recorded activities. The corresponding voluntary intake during mild (mean expenditure $378 \pm 63 \mathrm{kcal} / \mathrm{d}$ ) and moderate (mean expenditure $772 \pm 40 \mathrm{kcal} / \mathrm{d}$ ) exercise was $117 \pm 5 \%$ and $122 \pm 6 \%$ of sedentary treatment. The resulting energy balance was $+10 \pm 71 \mathrm{kcal} / \mathrm{d}$ for sedentary, $+64 \pm 43 \mathrm{kcal} / \mathrm{d}$ for mild and $-116 \pm 92 \mathrm{kcal} / \mathrm{d}$ for moderate treatments. Thus with normal body energy reserves as in these normal weight women, the exercise-induced metabolic signals played a hyperphagic role in the regulation of energy intake, as the stability in body mass during sedentary $(55.1 \mathrm{~kg})$, mild $(55.9 \mathrm{~kg})$, and moderate $(55.7 \mathrm{~kg})$ was observed.

It should be noted that with the above moderate levels of PA, voluntary energy intake did not increase as much as expenditure. If the study were prolonged over a longer period of time, it would possibly result in negative energy balance. It was noted that the women had struggled to complete their treadmill assignments and that, possibly, a fatigue effect came into play. This situation is comparable with the one presented by Mayer et al., ${ }^{6}$ where exhaustion exerted an anorexic effect on the intake of heavily exercising rats. For the particular subjects of this study, exercise costing more than $700 \mathrm{kcal} / \mathrm{d}$ may be close to the maximum PA level that could be accomplished on a habitual basis. ${ }^{47}$

Nevertheless, this study indicates that unlike obese subjects, who do not match their energy intakes to energy expended through PA, lean subjects demonstrate an increase in energy intake and insignificant changes in body mass when exercised on a long-term basis. It is hypothesized that the absence of an increase in energy intake when increasing expenditure in obese subjects is based on their excess energy stores in the form of adipose tissue.

Adipose tissue is not only a lipid storing tissue but consists of functionally specialized tissues able to produce heat (in brown adipose tissue) and to produce or release a vast number of adipocytokines. ${ }^{50}$ The adipocytokines, under normal weight conditions, guarantee homeostasis of glucose and lipid metabolism, but their dysregulated production in the obese state is associated with 


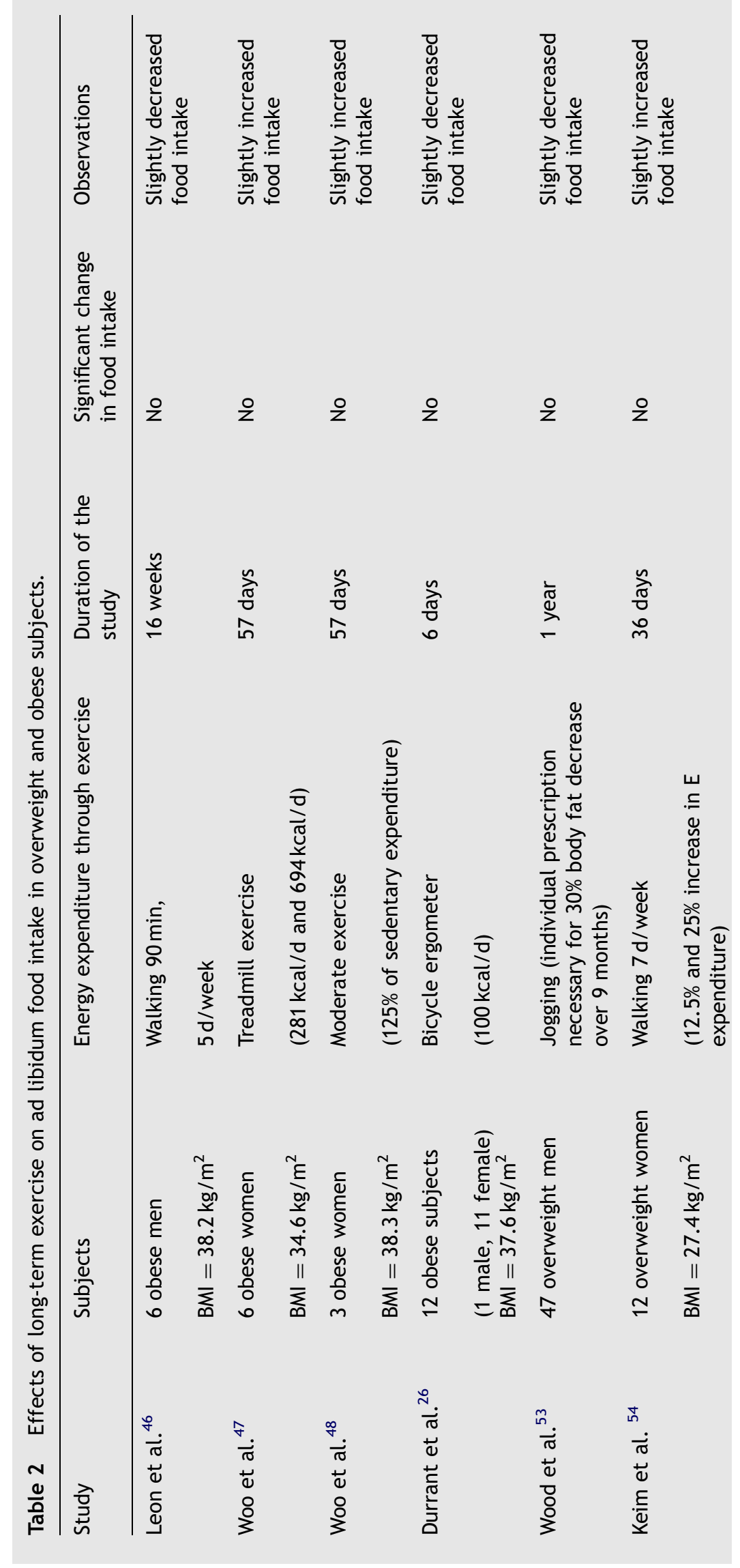




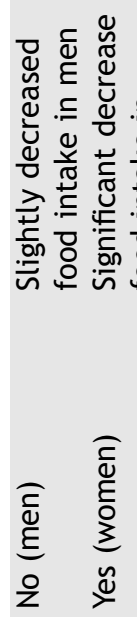

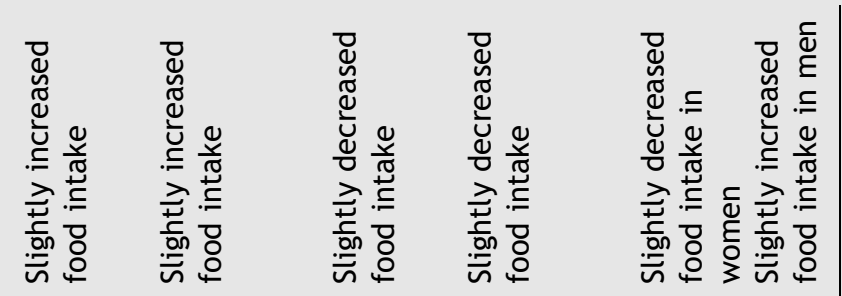

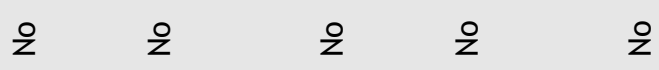
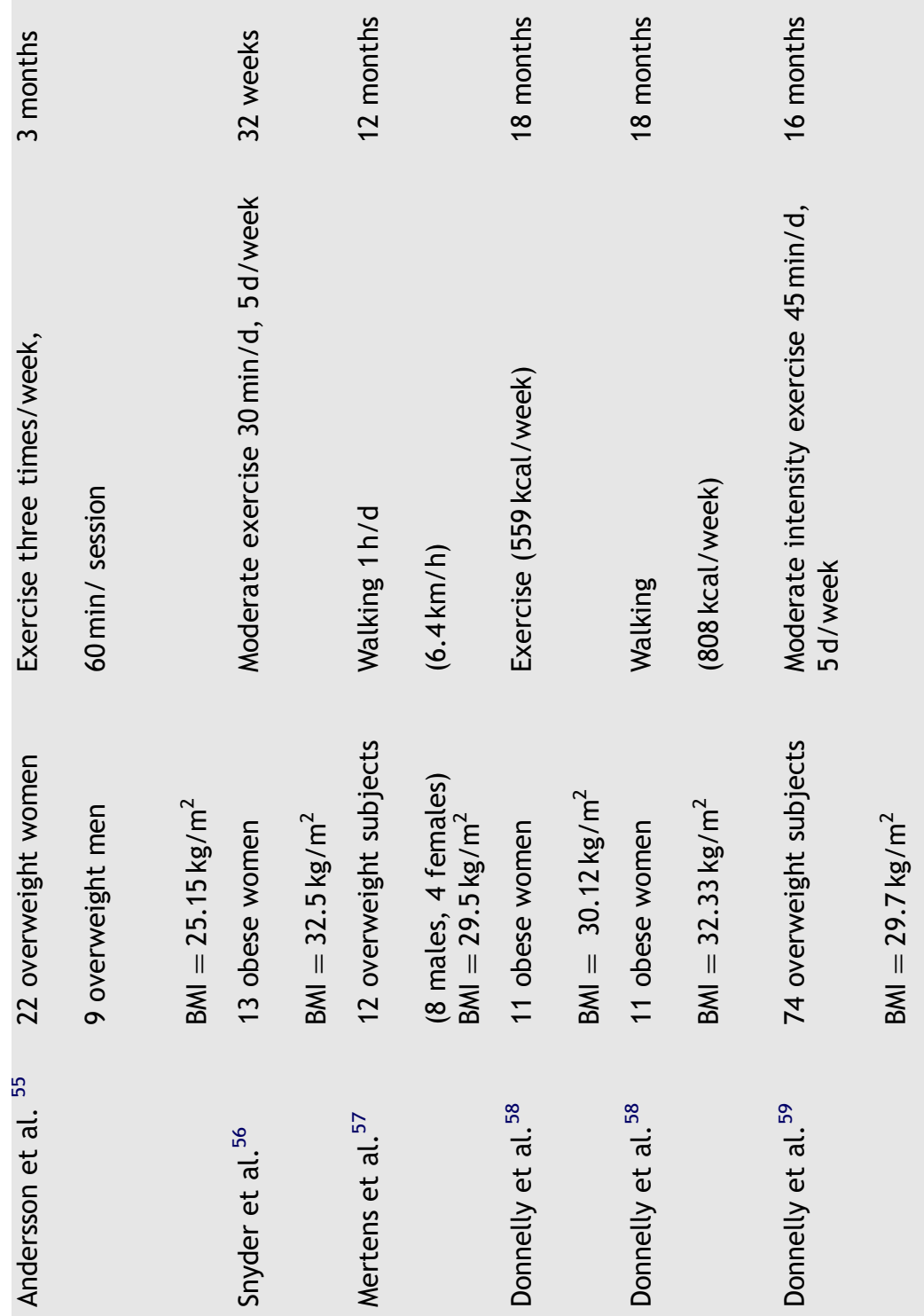
altered metabolic pathways, vascular pathologies and inflammatory processes. ${ }^{51}$ Thus, adipose tissue plays an active role in energy balance, and the responses of energy intake to exercise induced changes in energy expenditure may depend on the amount of body fat. It is likely that, in the obese state, fat mass acts as an energy buffer ${ }^{52}$ and that compensatory responses in intake to altered levels of exercise may not begin to act until the excess energy stores become depleted and the energy homeostasis is at risk. ${ }^{3}$

\section{Conclusion}

Increased energy expenditure due to short-term PA is not immediately compensated for by changes in energy intake. Once moderate to intense PA is performed regularly and on the long-term basis, however, a distinction has to be drawn between lean and obese subjects. While the lean show a tendency to balance the extra PA energy expenditure by adapting their energy intake accordingly within a period, of about 3 days, the obese, probably due to their excess energy storage, do not show such a compensatory mechanisms.

\section{Acknowledgement}

We thank the Foundation Nutrition 2000Plus for its financial support.

\section{References}

1. Bell C, Day DS, Jones PP, Christou DD, Petitt DS, Osterberg K, et al. High energy flux mediates the tonically augmented beta-adrenergic support of resting metabolic rate in habitually exercising older adults. J Clin Endocrinol Metab 2004; 89(7):3573-8.

2. Maughan RJ. Role of micronutrients in sport and physical activity. Br Med Bull 1999;55(3):683-90.

3. Woo R, Pi-Sunyer FX. Effect of increased physical activity on voluntary intake in lean women. Metabolism 1985;34(9): 836-41.

4. Melzer K, Kayser B, Pichard C. Physical activity: the health benefits outweigh the risks. Curr Opin Clin Nutr Metab Care 2004;7(6):641-7.

5. Amorim Cruz JA, Moreiras O, Brzozowska A. Longitudinal changes in the intake of vitamins and minerals of elderly Europeans. SENECA Investigators. Eur J Clin Nutr 1996; 50(Suppl. 2):S77-85.

6. Mayer J, Marshall NB, Vitale JJ, Christensen JH, Mashayekhi $M B$, Stare FJ. Exercise, food intake and body weight in normal rats and genetically obese adult mice. Am J Physiol 1954;177(3):544-8.

7. Mayer J, Roy P, Mitra KP. Relation between caloric intake, body weight, and physical work: studies in an industrial male population in West Bengal. Am J Clin Nutr 1956;4(2): 169-75.

8. Mayer J. Decreased activity and energy balance in the hereditary obesity-diabetes syndrome of mice. Science 1953;117(3045):504-5.

9. Murgatroyd PR, Goldberg GR, Leahy FE, Gilsenan MB, Prentice AM. Effects of inactivity and diet composition on human energy balance. Int J Obes Relat Metab Disord 1999;23(12):1269-75.

10. Schulz LO, Schoeller DA. A compilation of total daily energy expenditures and body weights in healthy adults. Am J Clin Nutr 1994;60(5):676-81.

11. Stubbs RJ, Hughes DA, Johnstone AM, Horgan GW, King $N$, Blundell JE. A decrease in physical activity affects appetite, energy, and nutrient balance in lean men feeding ad libitum. Am J Clin Nutr 2004;79(1):62-9.

12. Schoeller DA. Balancing energy expenditure and body weight. Am J Clin Nutr 1998;68(4):956S-61S.

13. Saris WH, Blair SN, van Baak MA, Eaton SB, Davies PS, Di Pietro L, et al. How much physical activity is enough to prevent unhealthy weight gain? Outcome of the IASO first stock conference and consensus statement. Obes Rev 2003;4(2):101-14

14. van Erp-Baart AM, Saris WH, Binkhorst RA, Vos JA, Elvers JW. Nationwide survey on nutritional habits in elite athletes. Part I. Energy, carbohydrate, protein, and fat intake. Int $J$ Sports Med 1989;10(Suppl. 1):S3-10.

15. Westerterp KR, Saris WH, van Es M, ten Hoor F. Use of the doubly labeled water technique in humans during heavy sustained exercise. J Appl Physiol 1986;61(6): 2162-7.

16. Saris WH, van Erp-Baart MA, Brouns F, Westerterp KR, ten Hoor F. Study on food intake and energy expenditure during extreme sustained exercise: the Tour de France. Int J Sports Med 1989;10(Suppl. 1):S26-31.

17. Westerterp KR. Limits to sustainable human metabolic rate. J Exp Biol 2001;204(Pt 18):3183-7.

18. Kayser B, Gremion G. Chronic fatigue and loss of performance in endurance athletes: overtraining. Schweiz Z Sportmed Sporttraumat 2004;52(1):1-10.

19. Blundell JE, King NA. Effects of exercise on appetite control: loose coupling between energy expenditure and energy intake. Int J Obes Relat Metab Disord 1988;22(Suppl. 2): S22-9.

20. King NA, Burley VJ, Blundell JE. Exercise-induced suppression of appetite: effects on food intake and implications for energy balance. Eur J Clin Nutr 1994;48: 715-24.

21. King NA, Lluch A, Stubbs RJ, Blundell JE. High dose exercise does not increase hunger or energy intake in free living males. Eur J Clin Nutr 1997;51(7):478-83.

22. Kissileff HR, Pi-Sunyer FX, Segal K, Meltzer S, Foelsch PA. Acute effects of exercise on food intake in obese and nonobese women. Am J Clin Nutr 1990;52(2):240-5.

23. Staten MA. The effect of exercise on food intake in men and women. Am J Clin Nutr 1991;53(1):27-31.

24. Stubbs RJ, Sepp A, Hughes DA, Johnstone AM, King N, Horgan $G$, et al. The effect of graded levels of exercise on energy intake and balance in free-living women. Int $\mathrm{J}$ Obes Relat Metab Disord 2002;26(6):866-9.

25. Lluch A, King NA, Blundell JE. Exercise in dietary restrained women: no effect on energy intake but change in hedonic ratings. Eur J Clin Nutr 1998;52(4):300-7.

26. Durrant ML, Royston JP, Wloch RT. Effect of exercise on energy intake and eating patterns in lean and obese humans. Physiol Behav 1982;29(3):449-54. 
27. Scheurink AJ, Ammar AA, Benthem B, van Dijk G, Sodersten PA. Exercise and the regulation of energy intake. Int $J$ Obes Relat Metab Disord 1999;23(Suppl. 3):S1-6.

28. King NA, Tremblay A, Blundell JE. Effects of exercise on appetite control: implications for energy balance. Med Sci Sports Exerc 1997;29(8):1076-89.

29. Schwartz MW, Woods SC, Porte Jr. D, Seeley RJ, Baskin DG. Central nervous system control of food intake. Nature 2000;404(6778):661-71.

30. Richard D. Exercise and the neurobiological control of food intake and energy expenditure. Int $J$ Obes Relat Metab Disord 1995;19(Suppl. 4):S73-9.

31. Woods SC, Seeley RJ, Porte Jr. D, Schwartz MW. Signals that regulate food intake and energy homeostasis. Science 1998;280(5368):1378-83.

32. Horvath TL, Diano S, Tschop M. Brain circuits regulating energy homeostasis. Neuroscientist 2004;10(3):235-46.

33. Woods SC, Seeley RJ. Adiposity signals and the control of energy homeostasis. Nutrition 2000;16(10):894-902.

34. Schwartz MW, Woods SC, Seeley RJ, Barsh GS, Baskin DG, Leibel RL. Is the energy homeostasis system inherently biased toward weight gain? Diabetes 2003;52(2):232-8.

35. Edholm OG, Adam JM, Healy MJ, Wolff HS, Goldsmith R, Best TW. Food intake and energy expenditure of army recruits. $B r$ J Nutr 1970;24(4):1091-107.

36. Saris WH. Lessons from the Tour the France. In: Kinney JM, Tucker NH, editors. Physiological stress and malnutrition: functional correlates, and nutritional intervention. New York: Lippincott-Raven; 1997. p. 451-61.

37. Edholm OG. Energy balance in man studies carried out by the Division of Human Physiology, National Institute for Medical Research. J Hum Nutr 1977;31(6):413-31.

38. Richard $D$, Rivest $S$. The role of exercise in thermogenesis and energy balance. Can J Physiol Pharmacol 1989;67(4): 402-9.

39. Balon TW, Zorzano A, Goodman MN, Ruderman NB. Insulin increases thermogenesis in rat skeletal muscle following exercise. Am J Physiol 1985;248(1 Pt 1):E148-51.

40. Thompson PD, Crouse SF, Goodpaster B, Kelley D, Moyna N, Pescatello $\mathrm{L}$. The acute versus the chronic response to exercise. Med Sci Sports Exerc 2001 (discussion S452-3).

41. Kantor MA, Cullinane EM, Herbert PN, Thompson PD. Acute increase in lipoprotein lipase following prolonged exercise. Metabolism 1984;33(5):454-7.

42. Pischon T, Hankinson SE, Hotamisligil GS, Rifai N, Rimm EB. Leisure-time physical activity and reduced plasma levels of obesity-related inflammatory markers. Obes Res 2003;11(9): 1055-64.

43. Havel PJ. Role of adipose tissue in body-weight regulation: mechanisms regulating leptin production and energy balance. Proc Nutr Soc 2000;59(3):359-71.

44. Jequier E, Tappy L. Regulation of body weight in humans. Physiol Rev 1999;79(2):451-80.

45. Pi-Sunyer FX, Woo R. Effect of exercise on food intake in human subjects. Am J Clin Nutr 1985;42(Suppl. 5):983-90.
46. Leon AS, Conrad J, Hunninghake DB, Serfass R. Effects of a vigorous walking program on body composition, and carbohydrate and lipid metabolism of obese young men. Am J Clin Nutr 1979; 32(9):1776-87.

47. Woo R, Garrow JS, Pi-Sunyer FX. Effect of exercise on spontaneous calorie intake in obesity. Am J Clin Nutr 1982;36(3):470-7.

48. Woo R, Garrow JS, Pi-Sunyer FX. Voluntary food intake during prolonged exercise in obese women. Am J Clin Nutr 1982;36(3):478-84.

49. Slentz CA, Duscha BD, Johnson JL, Ketchum K, Aiken LB, Samsa GP, et al. Effects of the amount of exercise on body weight, body composition, and measures of central obesity: STRRIDE-a randomized controlled study. Arch Intern Med 2004;164(1):31-9.

50. Klaus $\mathrm{S}$. Adipose tissue as a regulator of energy balance. Curr Drug Targets 2004;5(3):241-50.

51. Staiger H, Haring HU. Adipocytokines: fat-derived humoral mediators of metabolic homeostasis. Exp Clin Endocrinol Diabetes 2005;113(2):67-79.

52. Blundell JE, Stubbs RJ, Hughes DA, Whybrow S, King NA. Cross talk between physical activity and appetite control: does physical activity stimulate appetite? Proc Nutr Soc 2003;62(3):651-61.

53. Wood PD, Stefanick ML, Williams PT, Haskell WL. The effects on plasma lipoproteins of a prudent weight-reduc,ing diet, with or without exercise, in overweight men and women. N Engl J Med 1991;325:461-6.

54. Keim NL, Barbieri TF, Belko AZ. The effect of exercise on energy intake and body composition in overweight women. Int J Obes 1990;14(4):335-46.

55. Andersson B, Xu XF, Rebuffe-Scrive M, Terning K, Krotkiewski $M$, Bjorntorp P. The effects of exercise, training on body composition and metabolism in men and women. Int $\mathrm{J}$ Obes 1991;15(1):75-81.

56. Snyder KA, Donnelly JE, Jabobsen DJ, Hertner G, Jakicic JM. The effects of long-term, moderate intensity, intermittent exercise on aerobic capacity, body composition, blood lipids, insulin and glucose in overweight females. Int $\mathrm{J}$ Obes Relat Metab Disord 1997;21(12):1180-9.

57. Mertens DJ, Kavanagh T, Campbell RB, Shephard RJ. Exercise without dietary restriction as a means to long-term fat loss in the obese cardiac patient. J Sports Med Phys Fitness 1998;38(4):310-6.

58. Donnelly JE, Jacobsen DJ, Heelan KS, Seip R, Smith S. The effects of 18 months of intermittent vs. continuous exercise on aerobic capacity, body weight and composition, and metabolic fitness in previously sedentary, moderately obese females. Int J Obes Relat Metab Disord 2000;24(5): 566-72.

59. Donnelly JE, Kirk EP, Jacobsen DJ, Hill JO, Sullivan DK, Johnson SL. Effects of 16 mo of verified, supervised aerobic exercise on macronutrient intake in overweight men and women: the Midwest exercise trial. Am J Clin Nutr 2003;78(5):950-6.

Available online at www.sciencedirect.com

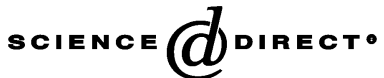

